\title{
Corrigendum: Annual Climatology of the Diurnal Cycle on the Canadian Prairies
}

\author{
Alan K. Betts ${ }^{1 *}$ and Ahmed B. Tawfik ${ }^{2}$ \\ ${ }^{1}$ Atmospheric Research, Pittsford, VT, USA, ${ }^{2}$ National Center for Atmospheric Research, Boulder, CO, USA
}

Keywords: land-atmosphere coupling, diurnal climate, Canadian prairies, cloud radiative forcing, wind coupling

\section{A corrigendum on}

Annual Climatology of the Diurnal Cycle on the Canadian Prairies

by Betts, A. K., and Tawfik, A. B. (2016). Front. Earth Sci. 4:1. doi: 10.3389/feart.2016.00001

OPEN ACCESS

Edited and reviewed by: Pierre Gentine,

Columbia University, USA

*Correspondence: Alan K. Betts akbetts@aol.com

Specialty section: This article was submitted to Atmospheric Science, a section of the journal Frontiers in Earth Science

Received: 21 March 2016 Accepted: 18 April 2016 Published: 02 May 2016

Citation: Betts AK and Tawfik AB (2016) Corrigendum: Annual Climatology of the Diurnal Cycle on the Canadian Prairies. Front. Earth Sci. 4:53. doi: 10.3389/feart.2016.00053
Reason for Corrigendum:

1: There was an error in the leading constant in the cold season $\mathrm{LW}_{n}$ regression in Equation (3b). The correct equation is

$$
\begin{aligned}
\mathrm{LW}_{\mathrm{n}}= & -112.2( \pm 9.8)+43.5( \pm 2.8) O P A Q_{\mathrm{m}}+26.8( \pm 2.5) O P A Q_{\mathrm{m}}^{2} \\
& +0.29( \pm 0.02) \mathrm{RH}_{\mathrm{m}}-1.02( \pm 0.03) \mathrm{T}_{\mathrm{m}}
\end{aligned}
$$

The authors apologize for the mistake. This error does not change the scientific conclusions of the article in any way. However, this error gave a y-axis offset for $\mathrm{LW}_{n}$ and $\mathrm{R}_{n}$ in Figure 5 (lower panels). The corrected version of Figure 5 follows.

\section{AUTHOR CONTRIBUTIONS}

$\mathrm{AB}$ made this error, and both authors approve the correction.

Conflict of Interest Statement: The authors declare that the research was conducted in the absence of any commercial or financial relationships that could be construed as a potential conflict of interest.

Copyright (c) 2016 Betts and Tawfik. This is an open-access article distributed under the terms of the Creative Commons Attribution License (CC BY). The use, distribution or reproduction in other forums is permitted, provided the original author(s) or licensor are credited and that the original publication in this journal is cited, in accordance with accepted academic practice. No use, distribution or reproduction is permitted which does not comply with these terms. 

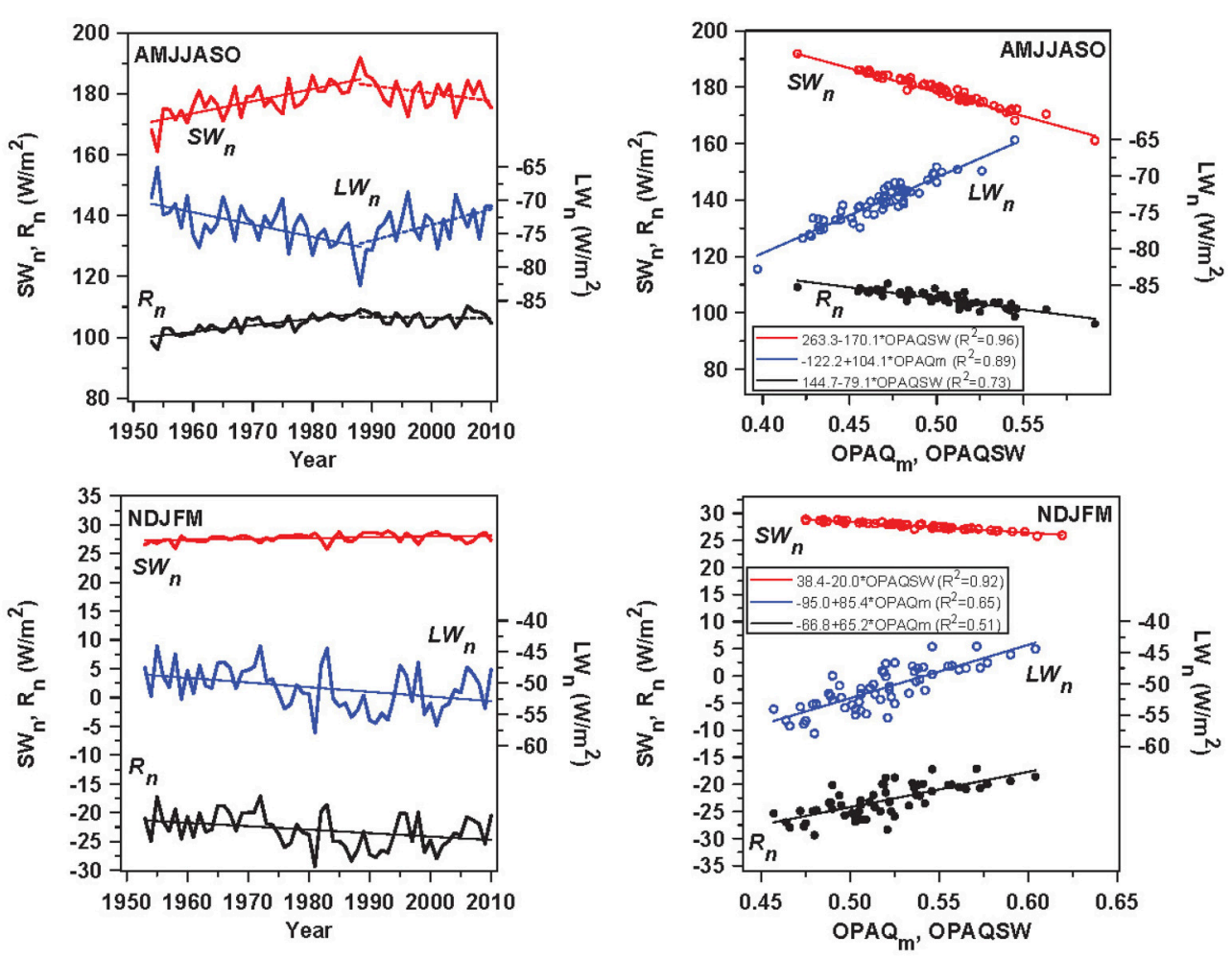

FIGURE 5 | Interannual variability of $\mathrm{SW}_{\mathrm{n}}, \mathrm{LW}_{\mathrm{n}}$, and $\mathbf{R}_{\mathrm{n}}$ for warm season (AMJJASO) and cold season (NDJFM) (left) and (right) regression of SW $\mathrm{h}_{\mathrm{n}}$ and $R_{n}$ on OPAQSW, $L W_{n}$ on OPAQ $Q_{m}$ in warm season (top); $S W_{n}$ on OPAQSW, $L W_{n}$, and $R_{n}$ on OPAQ $Q_{m}$ in cold season (bottom). 